\title{
Characterization of Fibrinolytic Enzymes Produced by the Halophilic Streptomyces Flaveolus and Streptomyces Galtieri Isolated from Wady El-Natron Area in North Egypt
}

\author{
MOHAMED E. OSMAN, M.D.*; SAID M. ABD EL-ALL, M.D.** and SHAMEL Y.E. KHALIFA, M.Sc.* \\ The Department of Botany and Microbiology, Faculty of Science, Helwan University* and The Microbiology Division, \\ National Organization for Drug Control and Research (NODCAR)**, Cairo, Egypt
}

\begin{abstract}
Background: Intravascular thrombosis is responsible for an increasing number of deaths every year. Lung blood clots in USA alone affect 1,000,000 patients annually. Clots formed from insoluble fibrin restrict the smooth flow of blood in blood vessels, leading to thrombosis and heart attacks. Worldwide, over $29 \%$ of the total mortalities are due to thrombosis, thus antithrombotic therapy is of great interest. The three fibrinolytic (thrombolytic) agents that are currently being used for this purpose are urokinase, streptokinase and genetically engineered tissue-type Plasminogen Activator (t-PA) However, these enzymes are expensive, thermolabile, with low specificity and stability, large therapeutic doses and can produce undesirable side effects such as gastrointestinal bleeding, allergic reactions, and resistance to repercussion. This warrants the search for novel fibrinolytic enzymes from various sources with higher efficacy, safety, specificity and stability and preferably those direct acting activities. Though new fibrinolytic enzymes are being explored from microbes, microorganisms remain the preferred source due to their biochemical versatility, feasibility of mass culture and ease of genetic manipulation. Hence, many fibrinolytic enzymes have been isolated from a variety of microorganisms, including actinomycetes, bacteria, fungi, and algae.
\end{abstract}

Aim of Study: To detect the characterization of fibrinolytic enzymes produced by the halophilic Streptomyces flaveolus and Streptomyces galtieri that were isolated from soil of Wady El-Natron region, in North Egypt, as a potential thrombolytic agent.

Material and Methods: Fibrinolytic enzymes, extracted from Streptomyces flaveolus and Streptomyces galtieri, were purified by ammonium sulfate precipitation and gel filtration. By using SDS-Page electrophoresis, determining their molecular masses, classified by inhibitory acting materials, characterized by determining metal ions influences, anticoagulation clotting time delay with $\mathrm{CaCl}_{2}$, their proteolytic activity in units $/ \mathrm{mg}$, the active conc. in $\propto \mathrm{g} / \mathrm{ml}$ and the least conc. in $\propto 1 / \mathrm{ml}$ of thrombolytic activity.

Results: The fibrinolytic enzymes extracted from both Streptomyces flaveolus and Streptomyces galtieri are classified

Correspondence to: Dr. Shamel Y.E. Khalifa,

E-Mail: shamelyoussef@yahoo.ca as metallo-protease enzymes, their molecular masses were $16 \mathrm{kDa}$ and $41 \mathrm{kDa}$, their proteolytic activity are 1.4 and 2.3 units/mg of proteins, the anticoagulation clotting time assay showed 20 and 15 min delay in clotting time with $\mathrm{CaCl}_{2}$, the active conc. of each enzyme was determined from the standard curve using streptokinase as standard fibrinolytic enzyme as 200 and $300 \propto \mathrm{g} / \mathrm{ml}$, and the least conc. of enzyme thrombolytic activity was measured by performing the modified Holmstrom method, as the crude thrombolytic activity were at concentrations of $80-100 \propto 1$, whereas, precipitated enzymes, showed thrombolytic activity at concentrations $20 \propto 1$ and $30 \propto 1 / \mathrm{ml}$ respectively. Metal ions exhibited different influences on the fibrinolytic enzyme actiyity produced by Streptomyces flaveolus, such as $\mathrm{Ca}, \mathrm{Cu}$ and $\mathrm{Fe}^{2+}$ promoted the activity of the enzyme, whereas $\mathrm{Mg}$ is strongly promoted it. But on the fibrinolytic enzyme activity produced by Streptomyces galtieri, $\mathrm{Cu}$ promoted the activity of the enzyme, whereas $\mathrm{Ca}$, partially inhibit the enzyme, but the $\mathrm{Fe}^{2+}$ and $\mathrm{Mg}$ were strongly and completely inhibit it

Conclusion: These results suggest that the extracted enzymes from both isolated Streptomyces flaveolus and Streptomyces galtieri are with potent and potential applications as thrombolytic agent.

Key Words: Fibrinolytic enzyme - Streptomyces - Milk clotting plate - Thrombolytic activity.

\section{Introduction}

LIFE threatening disease like myocardial infarction or commonly known as heart attack due to blood clot (Thrombosis) is one of the most widely occurring diseases in modern life. It occurs when injury on tissue occurs by the accumulation of fibrin (main protein component of blood clot). Normally, the fibrin formed in the blood from fibrinogen by the action of thrombin and is dissolved by the action of plasmin which is activated from plasminogen by tissue plasminogen activator [1]. The deposition of (unsolved clot by plasmin) leads to the formation of thrombus within the vascular system which obstructs the blood flow, causing a 
serious problem because it induces cerebral and cardiovascular disease [2]

According to a report published by the World Health Organization (WHO) in 2011, an estimated 17.3 million people died from cardiovascular diseases in 2008, representing 30\% of all global deaths [3], the WHO has also predicted that the situation will continue to worsen over time, by 2030 , about 23.6 million people is expected to die from CVDs every year [4].

There are many drugs used on fibrinolytic therapy such as urokinase, streptokinase produced by Streptococcus pyogenes and staphylokinase produced by Staphylococcus aureus were proved to be more effective for thrombolytic therapy [5] but all of them have side effects. Thrombolytic therapy today is expensive and has undesirable side effects such as the risk for internal hemorrhage within the intestinal tract when orally administrated [6].

Over the years, thrombolytic therapies via injecting or orally administrating thrombolytic agents to lyses thrombi in blood vessels have been extensively investigated [7]. Therefore, continuous efforts have been focused in the search of safer and less expensive thrombolytic agents from diverse sources. Until recently, fibrinolytic enzyme with potential thrombolytic application has been purified from various sources such as fermented food, earthworms, mushrooms, snake venom and microbial sources [8].

In recent years, various fibrinolytic enzymes produced by different microorganisms were in succession discovered [9], as important sources of thrombolytic agents. Therefore the searches for other fibrinolytic enzymes from various sources are being continued.

Microbial sources, such as bacteria, fungi and algae are reported to produce fibrinolytic enzyme with few reports on the use of Streptomyces sp [10].

Fibrinolytic enzyme is well known as a subclass of protease, which has an ability to degrade fibrin $[11,12]$.

Fibrinolytic proteases are the single class of enzymes which play an important part in the metabolism of many microorganisms like species of Staphylococcus [13], Penicillium [14], Asperigillus [15], Actinomyces [16], Streptomyces [17], Escherichia coli $[18]$ and Bacillus [19,20]
Streptomyces sp. produces several extracellular enzymes of commercial interest, such as protease, pectinase, xylanase and cellulase. Proteases constitute two thirds of the total number of enzymes used in industry and this is expected to increase. Some of these proteases are fibrinolytic enzymes capable of digesting fibrin [21] .

The main purpose for selecting the fibrinolytic enzyme produced by Streptomyces sp. is because it could be relatively inexpensive when compared to other thrombolytic agents and an alternative cure against cardiac blood clot.

The present study investigated the purification, biochemical characterization and thrombolytic activity of the fibrinolytic enzymes produced by Streptomyces flaveolus and Streptomyces galtieri isolated from different lakes's soil of Wady ElNatron region in North Egypt.

Thus, the present work aims to screen and characterize fibrinolytic enzymes from microorganisms especially actinomycetes that are deposited in culture collection.

\section{Material and Methods}

This study was done at the Regional Center for Mycology and Biotechnology, Al-Azhar University, in the period between January 2014 until December 2017.

1- Production of Fibrinolytic Enzyme from Streptomyces sp.: The process was carried out by growing them in a modified Cazpek broth medium [22], which consisted of the following ingredients (g/l): Casein, 5.0; sucrose, 5.0; $\mathrm{K}_{2} \mathrm{HPO}_{4}$, 30.0; $\mathrm{MgSO}_{4} \cdot 7 \mathrm{H}_{2} \mathrm{O}, 1.0 ; \mathrm{KCl}, 0.5$; and $\mathrm{Fe}_{2} \mathrm{SO}_{4} \cdot 7 \mathrm{H}_{2} \mathrm{O}$, 0.5 , all the ingredients were dissolved in $1000 \mathrm{ml}$ distilled water. The $\mathrm{pH}$ of the medium adjusted to $\mathrm{pH} 8$ for Streptomyces flaveolus and $\mathrm{pH} 7.5$ for Streptomyces galtieri before sterilization. $50 \mathrm{ml}$ of the media were transferred to $250 \mathrm{ml}$ conical flasks, sterilized by autoclaving at $121^{\circ} \mathrm{C}$ for $20 \mathrm{~min}$ and then cooled to room temperature. One $\mathrm{ml}$ of uniformly prepared spore suspensions $\left(10^{5}\right.$ spores $\mathrm{ml}^{-1}$ ) 7 days old cultures, were used as inocula. All cultures were incubated at $37^{\circ} \mathrm{C}$ for Streptomyces flaveolus and $30^{\circ} \mathrm{C}$ for Streptomyces galtieri, on rotary shaker at $200 \mathrm{rpm}$ for 5 days.

2- Extraction of fibrinolytic enzyme: After 5 days, the contents of the flasks filtered through Whatman No. 41 filter paper. Culture filtrates were centrifuged at 5000rpm for $15 \mathrm{~min}$ at $4^{\circ} \mathrm{C}$. The precipitates were discarded and the supernatants were used as the crude enzymes [22] 
3- Purification of fibrinolytic Enzyme: The crude enzyme $(50 \mathrm{ml})$ was placed in a salt-ice bath, $\left(\mathrm{NH}_{4}\right) 2 \mathrm{SO}_{4}$ was added, at varying concentration of $10-80 \%$ saturation with constant stirring under ice for $1 \mathrm{~h}$, precipitated protein was removed by centrifugation at $10000 \mathrm{rpm}$ for $30 \mathrm{~min}$ at $4^{\circ} \mathrm{C}$ and the supernatant was discarded. The precipitated protein was dissolved in $50 \mathrm{mM}$ Tris-HCl buffer ( $\mathrm{pH}$ 7.2). Proteins precipitated were determined by measuring absorbance at $280 \mathrm{~nm}$. Ammonium sulfate was removed using dialysis. The crude enzyme solution was purified using a DEAESepharose FF column. The major active fractions were pooled, concentrated with a YM10 ultra filtration membrane (Millipore Corporation, USA), and then subjected to gel filtration using a Sephadex G-50 column at a flow rate of $0.3 \mathrm{ml} / \mathrm{min}$. The active fraction was desalted and analyzed by SDSPage electrophoresis [23].

4- Total protein: Protein concentration was determined by the method of Lowry [24] using bovine serum albumin as a standard. The concentration of protein was determined by measuring the absorbance at $750 \mathrm{~nm}$.

5- SDS-PAGE and gel staining: SDS-PAGE [24] was carried out with the SDS trisglycine system (discontinuous) of Polyacrylamide slab gel of 160 $\mathrm{X} 140 \mathrm{X} 1.5 \mathrm{~mm}$ (length $\mathrm{X}$ width $\mathrm{X}$ thickness) dimension was used. Enzyme protein $(1.0 \mathrm{mg} / \mathrm{ml})$ dissolved in Tris- $\mathrm{HCl}$ buffer ( $\mathrm{pH} 8.3$ ) containing 0.5 per cent each of SDS and mercapto-ethanol was kept in a boiling water bath for $3 \mathrm{~min}$ in a tightly Stoppard vial. Fifty microlitres of this sample was loaded on the gel. For molecular weight determination, the standard proteins as markers used were with molecular weights from $97 \mathrm{kDa}$ to $10 \mathrm{kDa}$. The molecular weight was estimated by LabImage 1D L340 program.

6- Fibrinolytic activity: Fibrinolytic activity was detected by taking $2 \mathrm{ml}$ of human blood (informed consent) in $0.1 \mathrm{M}$ Phosphate Buffer, $\mathrm{pH}$ 7.4 , to this $0.1 \%$ of agarose was added and $0.2 \%$ of human fibrinogen was added. It was poured into a $10 \mathrm{~cm}$ petridish and allowed to clot. The clot was allowed to stand for $1 \mathrm{~h}$ at room temperature. Using the gel puncher wells was created and twenty micro liters of purified enzyme solution was carefully placed into the wells. The plate was incubated for $18 \mathrm{~h}$ at $37^{\circ} \mathrm{C}$ and the diameter of the lytic circle formed was measured. In this fibrin plate method, a clear transparent region is observed where fibrin is hydrolyzed. The active conc. of the enzymes activities were determined according to the standard curve using streptokinase as standard fibrinolytic enzyme. A series of Streptokinase standards with different dilutions 200 on the artificial fibrin plate and then incubated at $37^{\circ} \mathrm{C}$ for 10 hours. The lytic area diameter of each standard was measured. Then a standard curve was established with the logarithm of different activity on the $\mathrm{X}$-axis and the logarithm of the average of each lytic area diameter on the Y-axis. Therefore, the activity of each sample can be obtained according to the diameter of its lytic area [25]

7-Assay of protease activity: Protease activities of crude and purified enzymes were measured using casein as substrate and measured the release of peptide fragments. Reaction consisting of $0.5 \mathrm{ml}$ of $2 \%$ casein, $0.5 \mathrm{ml}$ of $0.2 \mathrm{M}$ Sodium phosphate buffer of pH 7.0 and $1 \mathrm{ml}$ of crude enzyme, incubated for $20 \mathrm{~min}$ at $37^{\circ} \mathrm{C}$. Reaction was stopped by the addition of $3 \mathrm{ml}$ of $0.15 \%$ TCA. Tyrosine was determined in the neat filtrate by measuring the absorbance at 570nm. One fibrinolytic enzyme unit is that amount of enzyme that liberates 1 molc of tyrosine in one min. under the assay conditions $[26,27]$

8-Determination of enzyme activity by modified Holmstrom method: The thrombolytic activity of the enzymes was checked using modified Holmstrorm method [28]; this is one of the most important methods to test the thrombolytic activity of an enzyme. In this method both crude and ammonium sulphate precipitated samples were used. one $\mathrm{ml}$ of human blood were taken in eppendroff tubes and allowed to clot. After the blood clotted completely, enzyme was added at a concentration of 10-100 The minimum concentration of the enzyme, which completely liquefies $1 \mathrm{ml}$ of clotted blood, is considered as one Enzyme Unit.

9- $\mathrm{CaCl}_{2}$-induced clotting time assay: $\mathrm{A} \mathrm{CaCl}_{2}$ induced clotting time assay [29] was developed for the determination of a $50 \%$ clotting time and effect on fibrin formation. The assay was performed by adding extracellular Streptomyces extract to human plasma and clotting was induced by the addition of $0.16 \mathrm{M} \mathrm{CaCl}_{2}$, clotting time was observed.

10- Effects of metal ions and inhibitors on protease enzyme activity: The enzyme extract can be classified by their sensitivity to various inhibitors and different metal ions [30]. The enzyme was incubated with different metal ions and inhibitors for 30min at room temperature and the residual activity was measured. The effects of metal ions such as $\mathrm{CaCl}_{2}, \mathrm{MgSO}_{4}, \mathrm{CuSO} 4$, and FeSO 4 and inhibitors such as EDTA, EGTA, and PMSF were measured. The enzyme activity measured without metal ions and inhibitors was considered as $100 \%$ (control). Each assay was carried out in triplicate. 


\section{Results}

1- Purification of fibrinolytic enzymes from Streptomyces flaveolus and Streptomyces galtieri: Extracellular crude enzyme proteins were precipitated using ammonium sulfate fractionation at different concentration from 10 to $80 \%$, maximum precipitation was at saturation $30 \%-40 \%$ for Streptomyces flaveolus, and at 50\%-60\% for Streptomyces galtieri. Proteins that precipitated were confirmed by checking absorbance at $280 \mathrm{~nm}$, followed by dialysis to remove ammonium salts for further studies. Spectrophotometric characterization has been done to characterize the precipitated proteins and the substance showed strong absorbance at $280 \mathrm{~nm}$ confirms the presence of protein. Proteins were estimated using the Lowry's method for all the Streptomyces extracts from both Streptomyces flaveolus and Streptomyces galtieri.

Table (1): Purification steps and results for Streptomyces flaveolus fibrinolytic enzyme.

\begin{tabular}{lccccc}
\hline \multicolumn{7}{c}{ Streptomyces flaveolus } \\
\hline Purification steps & $\begin{array}{c}\text { Total } \\
\text { protein } \\
(\mathrm{mg})\end{array}$ & $\begin{array}{c}\text { Total } \\
\text { activity } \\
(\mathrm{U})\end{array}$ & $\begin{array}{c}\text { Specific } \\
\text { activity } \\
(\mathrm{U} / \mathrm{mg})\end{array}$ & $\begin{array}{c}\text { Activity } \\
\text { recovery } \\
(\%)\end{array}$ & $\begin{array}{c}\text { Purifi- } \\
\text { cation } \\
\text { factor }\end{array}$ \\
\hline Crude extract & 416.2 & 40908 & 98.3 & 100 & 1 \\
Ammonium sulfate & 139.3 & 30421.4 & 218.4 & 74 & 2.2 \\
DEAE Sepharose FF & 22.1 & 20760.9 & 939.4 & 50.8 & 9.4 \\
Sephadex G-50 & 7.9 & 11331.8 & 1434.4 & 27.7 & 14 \\
\hline
\end{tabular}

Table (2): Purification steps and results for Streptomyces galtieri fibrinolytic enzyme.

\begin{tabular}{lccccc}
\hline \multicolumn{7}{c}{ Streptomyces galtieri } \\
\hline Purification steps & $\begin{array}{c}\text { Total } \\
\text { protein } \\
(\mathrm{mg})\end{array}$ & $\begin{array}{c}\text { Total } \\
\text { activity } \\
(\mathrm{U})\end{array}$ & $\begin{array}{c}\text { Specific } \\
\text { activity } \\
(\mathrm{U} / \mathrm{mg})\end{array}$ & $\begin{array}{c}\text { Activity } \\
\text { recovery } \\
(\%)\end{array}$ & $\begin{array}{c}\text { Purifi- } \\
\text { cation } \\
\text { factor }\end{array}$ \\
\hline Crude extract & 821.8 & 80862.2 & 98.4 & 100 & 1 \\
Ammonium sulfate & 295.1 & 60975.3 & 206.6 & 75 & 2.1 \\
DEAE Sepharose FF & 36.4 & 47498.8 & 1304.9 & 58.7 & 13 \\
Sephadex G-50 & 9.8 & 22964.4 & 2343.3 & 28.4 & 23 \\
\hline
\end{tabular}

Purification of both Streptomyces flaveolus and Streptomyces galtieri were carried out in three successive steps as shown in (Tables 1,2). The crude extract contained $416.2 \& 821.8 \mathrm{mg}$ protein, maximum activity was obtained in precipitation of $30 \%$ \& $50 \%$ saturation of ammonium sulfate. The major fractions with fibrinolytic activity were applied to the DEAE-Sepharose FF column, which generated one single peak showing fibrinolytic activity in the eluate. The major active fractions were pooled, concentrated, and further purified using gel filtration via a Sephadex G-50 column, and a single peak with a high specific activity was acquired. Overall, 14-fold purification and recovery of $27.7 \%$ activity (yield) in Streptomyces flaveolus and 23 -fold purification and recovery of $28.4 \%$ activity (yield) in Streptomyces galtieri were obtained after completion of the purification steps. The specific activity of the final enzymes preparation was $1434.4 \mathrm{U} / \mathrm{mg}$ protein and was $2343.3 \mathrm{U} / \mathrm{mg}$ protein. SDS-PAGE of the purified enzymes were performed to verify enzyme purity and determine the molecular mass. The proteins migrated as a single bands and the molecular mass of the active bands were estimated to be $16 \mathrm{kDa}$ and $41 \mathrm{kDa}$ for Streptomyces flaveolus and for Streptomyces galtieri respectively, Figs. $(1,2)$. The purified enzymes were designated as Streptomyces spp. fibrinolytic Metalloproteases.

\section{2- Total protein:}

Table (3): Total protein estimation (in $\mathrm{mg}$ ) before and after additions.

\begin{tabular}{lcc}
\hline Sample name & $\begin{array}{c}\text { Total protein } \\
\text { estimation } \\
\text { (control) (without } \\
\text { any addition) }\end{array}$ & $\begin{array}{c}\text { Maximum total protein estimation } \\
\text { (under optimized conditions) } \\
\text { (with addition of Xylose, } \\
\text { L-Methionine \& Saline) }\end{array}$ \\
\hline $\begin{array}{l}\text { - Streptomyces } \\
\text { flaveolus }\end{array}$ & $0.39 \mathrm{mg}$ & $1.78 \mathrm{mg}$ \\
\hline
\end{tabular}

SDS-PAGE

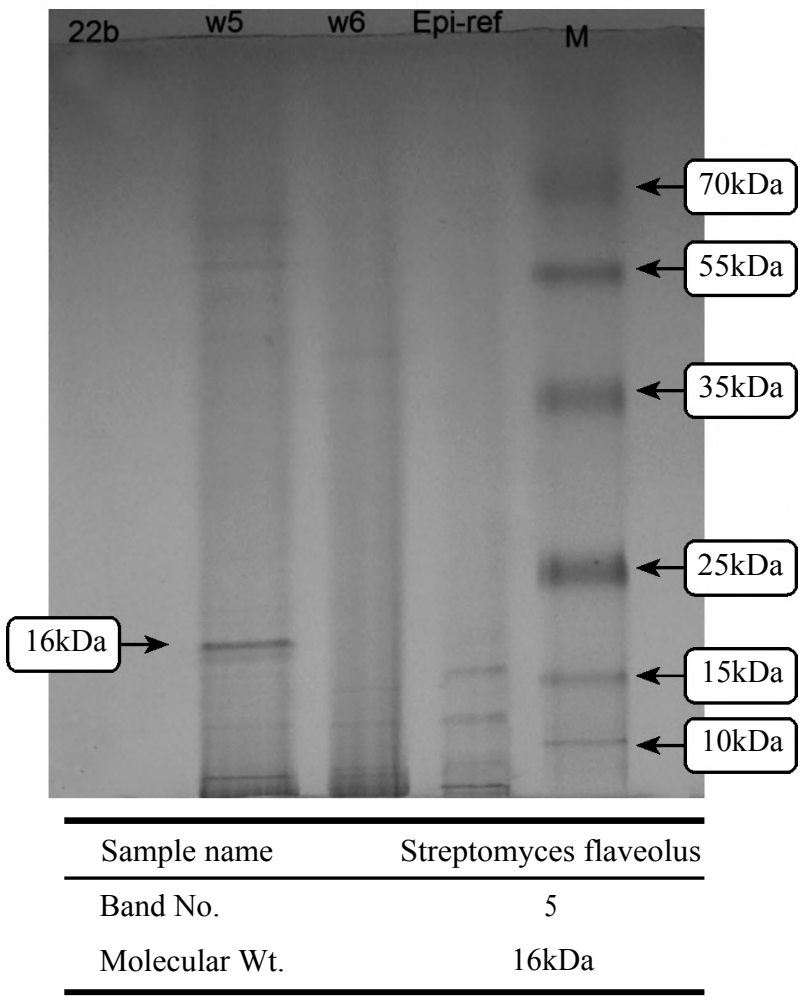

Fig. (1): SDS PAGE results for Streptomyces flaveolus fibrinolytic enzymes. 
SDS-PAGE was done to separate out our protein of choice from other cell precipitates based on molecular weight. Standard molecular weight markers were used to confirm the presence of fibrinolytic enzyme produced from Streptomyces flaveolus, which has a molecular weight of approximately $16 \mathrm{kDa}$.

Table (4): Total protein estimation (in $\mathrm{mg}$ ) before and after additions.

\begin{tabular}{lcc}
\hline Sample name & $\begin{array}{c}\text { Total protein } \\
\text { estimation } \\
\text { (control) (without } \\
\text { any addition) }\end{array}$ & $\begin{array}{c}\text { Maximum total protein estimation } \\
\text { (under optimized conditions) } \\
\text { (with addition of Xylose, } \\
\text { L-Glutamine \& Saline) }\end{array}$ \\
\hline $\begin{array}{l}\text { - Streptomyces } \\
\text { galtieri }\end{array}$ & $0.77 \mathrm{mg}$ & $2.70 \mathrm{mg}$ \\
\hline
\end{tabular}

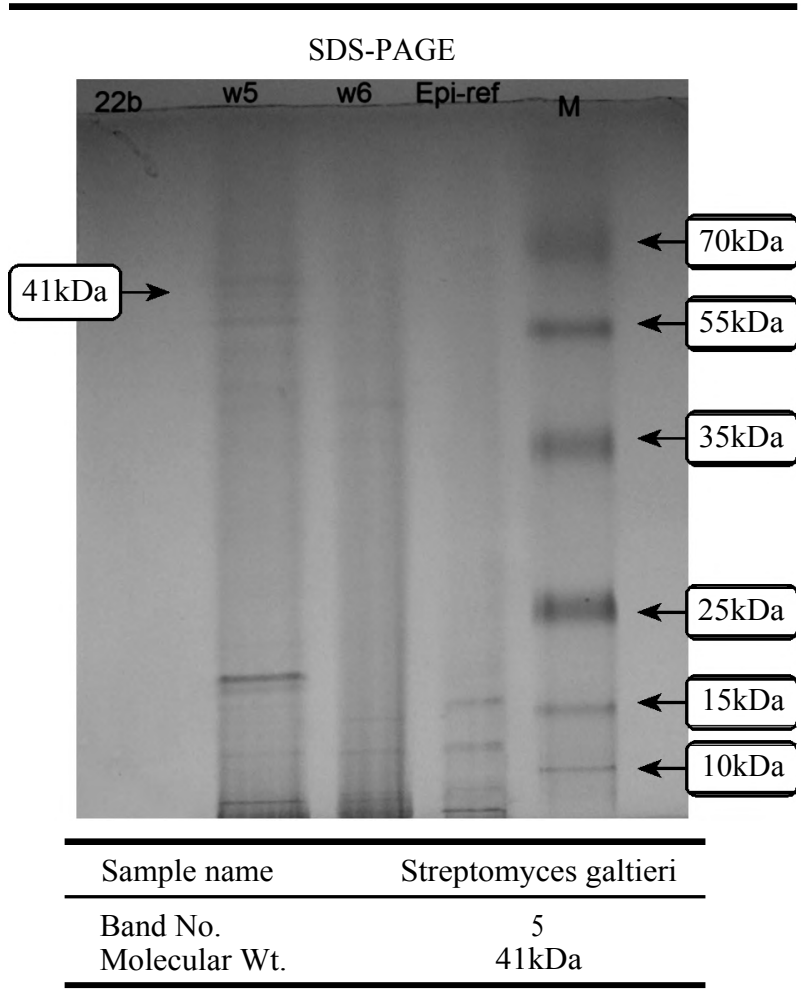

Fig. (2): SDS PAGE results for Streptomyces galtieri fibrinolytic enzymes.
The protein bands found on SDS PAGE for Streptomyces extract revealed that the molecular mass of the fibrinolytic enzyme from Streptomyces galtieri was approximately $41 \mathrm{kDa}$.

3- Assay of proteolytic enzymes: The purified enzymes from different Streptomyces isolates were tested to breakdown casein. The specific activity of Streptomyces flaveolus showed 1.4 units $\mathrm{mg}$ protein, and of Streptomyces galtieri showed 2.3 units $\mathrm{mg}$ protein (Table 5).

Table (5): Assay of proteolytic enzymes.

\begin{tabular}{lcc}
\hline Sample name & $\begin{array}{c}\text { Protein } \\
\mathrm{mg} / \mathrm{ml}\end{array}$ & $\begin{array}{c}\text { Specific activity } \\
\text { (Units/mg protein) } \\
\text { (Caseinolytic protein) }\end{array}$ \\
\hline Streptomyces flaveolus & $1.8 \mathrm{mg} / \mathrm{ml}$ & 1.4 Units $/ \mathrm{mg}$ protein \\
Streptomyces galtieri & $2.7 \mathrm{mg} / \mathrm{ml}$ & 2.3 Units $/ \mathrm{mg}$ protein \\
\hline
\end{tabular}

4- Fibrinolytic activity: By using fibrin plate method, graph was plotted using drug (streptokinase as standard) concentration Vs. lytic areas, the final concentration of fibrinolytic enzymes produced from Streptomyces flaveolus was $200 \mathrm{~g} / \mathrm{n}$ and from Streptomyces galtieri was 300 ond

5-Determination of enzyme activity by modified Holmstrom method: Holmstrom method confirmed the thrombolytic property of the isolated enzymes. Crude enzymes of Streptomyces flaveolus and Streptomyces galtieri showed thrombolytic property at concentration 20 Lar 40 Lalo, precipitated enzymes of Streptomyces flaveolus and Streptomyces galtieri showed thrombolytic property at 20 Lard 30 Lorards. Therefore, the least concentration that gives the complete lysis of $1 \mathrm{ml}$ of clotted blood in $18 \mathrm{~h}$, is only 20 units of the enzyme produced by Streptomyces flaveolus and 30 units of the enzyme produced by Streptomyces galtieri (Table 6).

Table (6): Modified Holmstrom method results showing the clot busting ability of the extracted enzyme as crude sample and precipitated sample showing the least concentration that gives the complete lysis of $1 \mathrm{ml}$ of clotted blood after incubation at $37^{\circ} \mathrm{C}$.

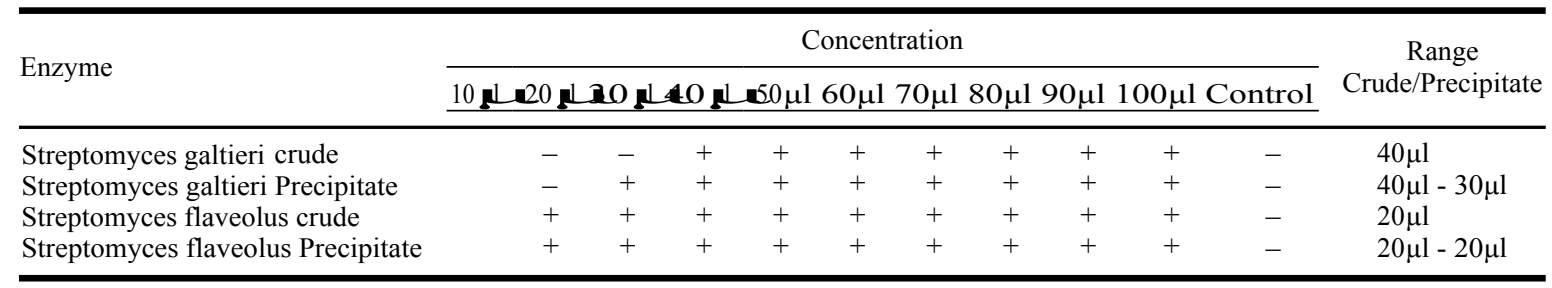

6- The effects of various inhibitors and metal ions on fibrinolytic enzymes produced by Streptomyces flaveolus and by Streptomyces galtieri: Streptomyces flaveolus enzyme and Streptomyces galtieri enzyme activities were strongly inhibited by EDTA and EGTA, (metallo-protease inhibitors). Metal ions influence on the fibrinolytic enzyme activity of Streptomyces flaveolus, such as $\mathrm{Ca}_{2+}$, 
$\mathrm{Cu}^{2+}$ and $\mathrm{Fe}^{2+}$ partially promoted it, whereas $\mathrm{Mg}^{2+}$ is strongly promoted it. But on the fibrinolytic enzyme activity of Streptomyces galtieri, $\mathrm{Cu}$ promoted it, whereas $\mathrm{Ca}$, partially inhibit it, but the $\mathrm{Fe}^{2+}$ and $\mathrm{Mg}^{2+}$ were strongly and completely inhibit it.

7- $\mathrm{CaCl}_{2}$-induced clotting time assay: $\mathrm{CaCl}_{2}$ induced clotting time assay, provided good results where coagulation time was delayed with the use of fibrinolytic enzymes in compared to the standard drug (Ibrofen), as the clotting was delayed for $20 \mathrm{~min}$ with Streptomyces flaveolus and $15 \mathrm{~min}$ with Streptomyces galtieri when compared with standard drug which having $25 \mathrm{~min}$ delay in coagulation.

Table (7): $\mathrm{CaCl}_{2}$ induced clotting time assay.

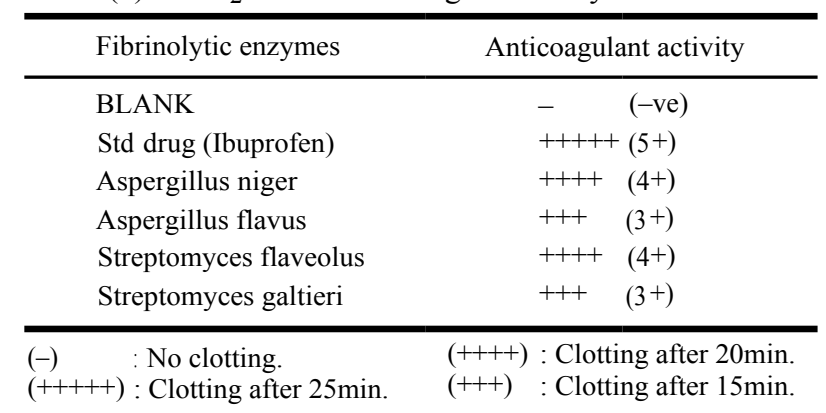

\section{Discussion}

The enzymes were purified using ammonium sulphate precipitation method. Ammonium sulphate contains sulphate which has cosmotropic and protein molecule exclusionary power. This property helps in effective precipitation of protein, where maximum amount of protein precipitated at 30 $40 \%$ in Streptomyces flaveolus and at $50-60 \%$ in Streptomyces galtieri.

SDSPAGE of fibrinolytic enzymes was done to determine the molecular weight of fibrinolytic enzymes along with other proteins. In SDS PAGE analysis protein bands are at around $16 \mathrm{kDa}$ for Streptomyces flaveolus and $41 \mathrm{kDa}$ for Streptomyces galtieri which indicates our target protein was extracted successfully. The results suggesting that they correspond to the fibrinolytic enzymes, as the molecular mass of the reported microbial fibrinolytic enzymes is in the range of 14.4-66.2kDa [31], thus, they are similar to that of fibrinolytic enzyme from Streptomyces megaspores SD5 and Streptomyces sp. CS684.

The molecular mass of the purified enzyme from Streptomyces flaveolus ( $16 \mathrm{kDa}$ ) was similar to as that for the fibrinolytic enzyme from $P$. eryngii $(14 \mathrm{kDa})[32]$ and was similar to that of the fibrino- lytic enzyme from A. mellea (21kDa) [33]. However, the fibrinolytic enzyme obtained in this study from Streptomyces flaveolus was smaller than that from Cordyceps militaris $(52 \mathrm{kDa})[34,47]$, the subtilisin DFE from B. amyloliquefaciens DC-4 (28kDa) [35], the fibrinolytic enzyme from Bacillus sp. KA38 (41kDa) [36], B. subtilis KCK-7 (44kDa) [37] and the fibrinolytic enzyme from Bacillus sp. KDO-13 (45kDa) [38] .

While, the molecular mass of the purified enzyme from Streptomyces galtieri $(41 \mathrm{kDa})$ was the same as the fibrinolytic enzyme from Bacillus sp. KA38 (41kDa) [36], and was similar to B. subtilis KCK-7 (44kDa) [37], and was similar to the fibrinolytic enzyme from Bacillus sp. KDO-13 (45kDa) [38]. However, the fibrinolytic enzyme obtained in this study from Streptomyces galtieri was smaller than that from C. militaris $(52 \mathrm{kDa})[34$ ] and was much larger than the subtilisin DFE from B. amyloliquefaciens DC-4 (28kDa) [35].

The purified enzymes from different Streptomyces isolates were tested to breakdown casein. The results showed that all the purified samples from different Streptomyces isolates tested have proteolytic activity. The specific activities of the fibrinolytic enzymes produced by different microbial isolates ranged from 15.02 to $33.66 \mathrm{U} / \mathrm{ml}$. In this study, Streptomyces flaveolus showed 1.4 units $\mathrm{mg}^{-1}$ protein, and Streptomyces galtieri showed 2.3 units $\mathrm{mg}^{-1}$ protein (Table 5). It coincides with the results reported by Srinivasan, et al. [39], as specific activity of fibrinolytic proteases from Aspergillus flavus showed 1.4 units mg protein, Penicillium showed 1.3 units $\mathrm{mg}^{-1}$ protein and Aspergillus niger showed 1 units mg protein. Simkhada et al. [40], reported a fibrinolytic protease from Streptomyces sp. CS684 that had a specific activity of 19U/mg. Ju et al. [41], purified a fibrinolytic enzyme from Streptomyces sp. XZNUM 00004 that has a specific activity of $530.0 \mathrm{IU} / \mathrm{mg}$. Hyeon-Deok et al. [42] and Chang et al. [43], reported fibrinolytic enzyme from 1-isolated-from-therhizosphere-of-acacia-cyanophlla-lindey.php? aid=8408"Bacillus subtilisHYPERLINK "http: // ejbio.imedpub.com/immobilization-of-945amylasefrom-bacillus-subtilis-sdp 1-isolated-from-therhizosphere-of-acacia-cyanophlla-lindey.php? aid $=8408$ " and Bacillus amyloliquefaciens MJ541 that had a specific activity of $21.6 \mathrm{U} / \mathrm{mg}$ and $3.44 \mathrm{U} / \mathrm{mg}$ respectively.

Fibrinolytic enzyme activity was determined by fibrin plate method. Graph was plotted using drug (streptokinase as standard) concentration Vs. lytic area to detect the concentration of fibrinolytic 
enzymes. In fibrin plate method, the lytic areas created by the fibrinolytic enzymes produced from the Streptomyces flaveolus and Streptomyces galtieri had been measured and compared with the standard fibrin plate to check the concentration of fibrinolytic enzymes. The final concentration of fibrinolytic enzymes produced from Streptomyces flaveolus was $200 \mathrm{~g} / \mathrm{n}$ and from Streptomyces galtieri was 300 s/m

The presence of fibrinolytic enzyme was proved in proteolytic assay where that was the index for fibrinolytic activity. Most of the in vitro methods that were usually or at present applied to study thrombolysis have many limitations. Some involve tedious calculations and mathematical skills that to give only theoretical prediction of the outcome and most are expensive to be performed in a laboratory. In context to that, Holmstrom method is easy to perform and is with low cost effective too. After performing the modified Holmstrom method, it was seen that both enzymes showed thrombolytic activity at concentrations of 80-100 the other hand, the precipitated enzymes showed clot lysis activity at fairly lower concentrations. Precipitated fibrinolytic enzymes produced by Streptomyces flaveolus and Streptomyces galtieri showed the clot lysis activity at a minimum concentration of 20 ared 30 rectively, whereas the crude enzymes showed the same activity at a concentration of 20 Lan 40 repectively as seen in (Table 6). Madhuri Doss H et al., 2011 reported that $0.12 \mathrm{ml}(120)$ Streptokinase [44] liquefied $1 \mathrm{ml}$ of clotted blood in $18 \mathrm{~h}$, whereas in the present study, only $0.02 \mathrm{ml}(20)$ and $0.04 \mathrm{ml}(40)$ at the extracted fibrinolytic enzymes produced by Streptomyces flaveolus and Streptomyces galtieri respectively, gave the same results which coincides with the results reported by Srinivasan, V. Mohana et al., (2013), as Staphylokinase showed thrombolytic activity at conc. 10 Thus, based on our results it can be inferred that fibrinolytic enzymes produced by Streptomyces flaveolus and Streptomyces galtieri showed the best thrombolytic activity as compared to the other.

Thrombolytic therapy demands a more clot specific third generation molecule which will work efficiently in shorter duration with minimum side effects. Native Streptomyces fibrinolytic enzyme is useful for cost-effective thrombolytic therapeutic purposes in clinical areas. Large quantities of Streptomyces fibrinolytic enzyme can be produced inexpensively by Actinomycetes strains [48]. The fibrinolytic enzyme produced by Streptomyces spp. is a better thrombolytic agent than any other chemical agents like Heparin and EDTA. The present study, showed that the enzymes produced by Streptomyces flaveolus and Streptomyces galtieri can show maximum activity at concentrations as low as 20 an 40 Thrombolytic agents with such low active concentrations can be very useful for preparation of commercial formulation. Furthermore, various biophysical and chemical modifications are being used to extend the half-life when in the circulatory system of human.

As for both Streptomyces flaveolus enzyme and Streptomyces galtieri enzyme extracts, the enzymes activities were strongly inhibited by EDTA and EGTA, (metallo-protease inhibitors). This result suggests that the fibrinolytic enzymes of Streptomyces flaveolus and Streptomyces galtieri are classified as metallo-protease enzymes. Additionally, metal ions exhibited a different influence on the fibrinolytic enzyme activity of Streptomyces flaveolus, such as $\mathrm{Ca}_{2+}, \mathrm{Cu}^{2+}$ and $\mathrm{Fe} 2+$ partially promoted the activity of the fibrinolytic enzyme, whereas $\mathrm{Mg}^{2+}$ is strongly promoted it. But on the fibrinolytic enzyme activity of Streptomyces galtieri, $\mathrm{Cu}^{2+}$ promoted the activity of the fibrinolytic enzyme, whereas $\mathrm{Ca} 2+$, partially inhibit it, but the $\mathrm{Fe} 2+$ and $\mathrm{Mg}^{2+}$ were strongly and completely inhibit it. These results are similar to a fibrinolytic enzyme from the isolated marine bacterium Bacillus subtilis ICTF- 1 [45] and NJP [46]

$\mathrm{CaCl}_{2}$-induced clotting time assay is the most important assay to evaluate the anticoagulant activity of microbial species. Data concerning the anticoagulant activity of different fibrinolytic enzymes shown in (Table 7). Ibuprofen was used as standard anti-Coagulant. Ibuprofen showed higher anti-coagulating activity than microbial fibrinolytic enzymes where plasma clotting was occurred after $25 \mathrm{~min}$, with the standard Ibuprofen, whereas, Aspergillus niger and Streptomyces flaveolus fibrinolytic enzyme caused clotting for plasma after 20min, while, Streptomyces galtieri and Aspergillus flavus fibrinolytic enzymes caused clotting for plasma after $15 \mathrm{~min}$ which coincides with that reported by Srinivasan, V. Mohana; 2013 [39] .

\section{Conclusion:}

The fibrinolytic enzymes produced by Streptomyces flaveolus and Streptomyces galtieri that were extracted have good clot bursting ability and are comparable to the other plasminogen activators, such as streptokinase, urokinase, nattokinase and tissue plasminogen activator. Finally, we concluded that fibrinolytic enzymes produced using different Streptomyces spp. provides good source for fibrinolytic enzymes that can be produced in high 
quality and quantity in short time, in high salinity and its characterization by mentioned assay above, specify that over all activity is too good and may be considered for large scale production.

\section{Acknowledgement:}

Authors wish to thank, Dr. Ghada Awad, Department of Biotechnology, (NRC), Dr. Amina Abdl-Hamid, Department of Biotechnology, (A.G.I.R.I.), Dr. Amal Saaid, Department of Biochemistry, (NODCAR) and Dr. Mohamed Warda, Department of Biochemistry, Faculty of Veterinary medicine for their support and guidance in doing the research work and also, would like to thank them for their constant support.

\section{References}

1- FAREED J., LEONG W.L., HOPPENSTEADT D.A., et al.: Generic low-molecular weight heparins: Some practical considerations, Semin. Thromb. Haemost., 30: 703-13, 2004.

2- DEEPAK V., ILANVAN S., SAMPATHKUMAR M.V., VICTORIA M.J., PASHA S.P.B.S., PANDIAN S.B.R.K. and GURUNATHAN S.: Medium optimization and immobilization of purified fibrinolytic URAK from Bacillus cereus NK1 on PHB nanoparticles. Enzyme Microbiology and Technology, 47: 297-304, 2010.

3- WHO: Global status report on noncommunicable diseases 2010. World Health Organization; Geneva, Switzerland, pp. 9-31, 2011.

4- MATHERS C.D. and LONCAR D.: Projections of global mortality and burden of disease from 2002 to 2030. PLoS Med. Pub. Med., 3: e442, 2006.

5- FARIAS,W.R.L., VALENTE A.P., PEREIRA M.S. and MOURA O.P.A.S.: J. Biol. Chem., 275: 29299-307, 2000.

6- ZHANG L., ZHANG Z.G., LIU X.S., SOLGOT A. and CHOPP M.: The PI3K/Akt Pathway Mediates the Neuroprotective Effect of Atorvastatin in Extending Thrombolytic Therapy After Embolic Stroke in the Rat. Arteriosclerosis, Thrombosis and Vascular Biology, 27: 2470-5, 2007.

7- PENG Y., XIAOJUAN Y. and YIZHENG Z.: Microbial fibrinolytic enzymes: An overview of source, production, properties, and thrombolytic activity in vivo. Applied Microbiology and Biotechnology, 69: 126-32, 2005.

8- KOTB E.: The biotechnological potential of fibrinolytic enzymes in the dissolution of endogenous blood thrombi. Biotechnology Progress, 30: 656-72, 2014.

9- PEREIRA M.S., MULLOY B. and MOURA O.P.A.S.: J. Biol. Chem., 274: 7656-67, 1999.

10 - CHITTE R.R., DESHMUKH S.V. and KANEKAR P.P.: Production, purification, and biochemical characterization of a fibrinolytic enzyme from thermophilic Streptomyces sp. MCMB-379. Applied Biochemistry and Biotechnology, 165: 1406-13, 2011.

11- JEONG Y.K., YANG W. S., KIM K.H., CHUNG K.T., LOO W.H. and PARK J.U.: Purification of a fibrinolytic enzyme (myulchikinase) from pickled anchovy and its cytotoxicity to the tumer cell lines. Biotechnol. Lett., 26: 393-7, 2004.

12- WONG A.H. and MINE Y.: Novel fibrinolytic enzyme in fermented shrimp paste, a traditional asian fermented seasoning. J. Agric. Food Chem., 52: 980-6, 2004.

13- BERDZULISHVILI E.M., AFANASEVA T.I. and ALERGANT A.P.: Fibrinolytic activity of pathogrnic staphylococci of different origins. Lab. Delo., 6: 332-4, 1973.

14- ANDREEVA N.A., USHAKOVA V.I. and EGOROV N.S.: Study of proteolytic enzymes of various strains of penicillium lilacinum in relation to their fibrinolytic activity. Mikrobiologiia, 4: 417-22, 1972.

15- LARCHER G., BOUCHARA J.P. and TRONCHIN G.: Purification and characterization of a fibrinogenolytic serine proteinase from Asperigillus fumigates culture filtrate. Febs. Lett., 10: 65-9, 1992.

16- EGOROV N.S., KOCHETOV G.A. and KHAIDAROVA N.V.: Isolation and properties of the fibrinolytic enzyme from Actinomyces thermovulgaris culture broth. Mikrobiologiia, 45: 455-9, 1976.

17- CHITTE R.R. and DEY S.: Potent fibrinolytic enzyme from a thermophilic Streptomyces megaspores strain SD5. Lett. Appl. Microbiol., 31: 405-10, 2000.

18- MALKE H. and FERRETTI: Streptokinase cloning expression and excretion by Escherichia coli. Proc. Natl. Acad. Sci. USA, 81: 57-61, 1984.

19- YU R., QI H., ZHANG T. and WU W.T. : Preliminary studies on in vitro and in vivo thrombolytic activities of thrombolytic enzyme from an induced Bacillus subtilis strain. Schuan Da Xue Xue Bao Yi Xue Ban, 36: 93-6, 2005.

20- PENG Y., HUANG Q., ZHANG R.H. and ZHANG Y.Z. Purification and characterization of a fibrinolytic enzyme produced by Bacillus amyloliquefaciens DC-4 screen from douche, a traditional Chinese soybean food. Comp. Biochem. Physiol. Biochem. Mol. Biol., 134: 45-52, 2003.

21- SILVA G.M.M., BEZERRA R.P., TEIXEIRA J.A., PORTO T.S., LIMA-SILVA J.L. and PORTO A.L.F.: Fibrinolytic protease production by new Streptomyces sp. DPUA 1576 from Amazon lichens. Electronic Journal of Biotechnology, 18: 16-9, 2015.

22- RASHMI B.S. and LINY P.: Production and characterization of novel fibrinolytic enzyme from different soil fungal sp. Int. J. Pharm. Bio. Sci., July, 4 (3): (B) 454-63, 2013.

23- LAEMMLI U.K.: "Cleavage of structural proteins during the assembly of the head of bacteriophage T4". Nature, 227 (5259): 680-5, 1975.

24- LOWRY O.H., ROSEBROUGH N.J., FARR A.L. and RANDALL R.J.: J. Biol. Chem., 193, 265, 1951.

25- KUMARAN S., PALANI P., CHELLARAM1 C., PREM ANAND P. and KAVIYARASAN V.: Screening of fibrinolytic protease from south indian isolates of ganoderma lucidum, International Journal of Pharma and Bio Sciences, Vol 2/Issue 1/Jan.-Mar. 2011, 2011.

26- PATIL M. and SHASTRI N.V.: Indian J. Microbiol., 22: 115, 1982. 
27- ASTRUP T. and MULLERTZ S.: The fibrin plate method for estimating fibrinolytic activity. Arch. Biochem., 40: 346-51, 1952.

28- SWETA PRASAD, RAJPAL S. KASHYAP1, JAYANT Y. DEOPUJARI, HEMANT J. PUROHIT, GIRDHAR M. TAORI and HATIM F. DAGINAWALA: Development of an in vitro model to study clot lysis activity of thrombolytic drugs. Thrombosis Journal, 4: 14-8, 2006.

29- USA Pharmacopoeia: Pharmacopoeia of United States of America. Mack Publishing Company, 482, 1985.

30- GERMANA MICHELLE De MEDEIROS E. SILVA, RAQUEL PEDROSA BEZERRA, JOSÉ ANTÓNIO TEIXEIRA, et al.: Screening, production and biochemical characterization of a new fibrinolytic enzyme produced by Streptomyces sp. (Streptomycetaceae) isolated from Amazonian lichens. Acta. Amaz. Vol. 46, No. 3 Manaus, 2016.

31- LU F., LU Z., BIE X., YAO Z., WANG Y., LU Y. and GUO Y.: Purification and characterization of a novel anticoagulant and fibrinolytic enzyme produced by endophytic bacterium Paenibacillus polymyxa EJS-3. Thromb. Res., 126: e349-e355, 2010.

32- CHA W.S., PARK S.S., KIM S.J. and CHOI D.: Biochemical and enzymatic properties of a fibrinolytic enzyme from Pleurotus eryngii cultivated under solid-state conditions using corn cob. Bioresour. Technol., 101: 6475-81, 2010.

33- LEE S.Y., KIM J.S., KIM J.E., SAPKOTA K., SHEN M.H., KIM S., et al.: Purification and characterization of fibrinolytic enzyme from cultured mycelia of Armillaria mellea. Protein Express. Purif., 43: 10-7, 2005.

34- KIM J., SAPKOTA K., PARK S., CHOI B., KIM S., HIEP N.T., et al.: A fibrinolytic enzyme from the medicinal mushroom Cordyceps militaris. J. Microbiol., 44: 622, 2006.

35- PENG Y., HUANG Q., ZHANG R.H. and ZHANG Y.Z. Purification and characterization of a fibrinolytic enzyme produced by Bacillus amyloliquefaciens DC-4 screened from douchi, a traditional Chinese soybean food. Comp. Biochem. Physiol., B 134: 45-52, 2003.

36- KIM H.K., KIM G.T., KIM D.K., CHOI W.A., PARK S.H., JEONG Y.K. and KONG I.S.: Purification and characterization of a novel fibrinolytic enzyme from Bacillus sp. KA38 originated from fermented fish. J. Ferment. Bioeng., 84: 307-12, 1997.

37- PAIK H.D., LEE S.K., HEO S., KIM S.Y., LEE H.H. and KWON T.J.: Purification and characterization of the fibrinolytic enzyme produced by Bacillus subtilis KCK7 from chungkookjang. J. Microbiol. Biotechnol., 14: 829-35, 2004.
38- LEE A., SI-KYUNG L., BAE D.H., KWON T.J., LEE S.B., LEE H.H., et al.: Purification and characterization of a fibrinolytic enzyme from Bacillus sp. KDO-13 isolated from soybean paste. J. Microbiol. Biotechnol., 11: 845$52,2001$.

39- SRINIVASAN V. MOHANA, DEVI C. SUBATHRA, SAHA AKATA, MONDAL MADHUMANTI, DHAR SUDESHNA, SUGANTHI V. and SELVARAJAN E.: Screening for staphylokinase producing staphylococcus spp. from bovine milk sample, International Journal of Pharmacy \& Pharmaceutical Sciences, Vol. 5, Issue 2, p. 601, 2013.

40- SIMKHADA J.R., MANDER P., CHO S.S. and YOO J.C.: A novel fibrinolytic protease from Streptomyces $\mathrm{sp}$ CS684. ProcBiochem., 45: 88-93, 2010.

41- JU X., CAO X., SUN Y., WANG Z., CAO C. and LIU J., JIANG J.: Purification and characterization of a fibrinolytic enzyme from Streptomyces sp. XZNUM 00004. World J. Microbiol. Biotechnol., 28: 2479-86, 2012.

42- HYEON-DEOK J., LEE H.A., JEONG S.J. and KIM J.H.J.: Purification and characterization of a major fibrinolytic enzyme from Bacillus amyloliquefaciens MJ5-41 isolated from Meju. Microbiol. Biotechnol., 21: 1166-73, 2011.

43- CHANG C.T., WANG P.M., HUNG Y.F. and CHUNG Y.C.: Purification and biochemical properties of a fibrinolytic enzyme from Bacillus subtilis-fermented red bean Food Chem., 133: 1611-7, 2012.

44- MADHURI DOSS H., MADHURI MANOHAR, NEHA ATUL SINGH, MOHANA SRINIVASAN V. and SUBATHRA DEVI C.: Studies on isolation, Screening and strain improvement of streptokinase producing [3-hemolytic Streptococci, World Journal of Science and Technology, 1: 07-11, 2011.

45- MAHAJAN P.M., NAYAK S. and LELE S.S.: Fibrinolytic enzyme from newly isolated marine bacterium Bacillus subtilis ICTF-1: Media optimization, purification and characterization. J. Biosci. Bioeng., 113: 307-14, 2012.

46- WANG S., DENG Z., LI Q., GE X., BO Q., LIU J., et al.: A novel alkaline serine protease with fibrinolytic activity from the polychaete, Neanthes japonica. Comp. Biochem. Physiol., B 159: 18-25, 2011.

47- BALARAMAN K. and PRABAKARAN G.: Production \& purification of a fibrinolytic enzyme (thrombinase) from Bacillus sphaericus, Indian J. Med. Res., 126, pp. 459-64, 2007.

48- JIN T., BOKAREWA M., FOSTER T., MITCHELL J., HIGGIN J. and TARKOWSKI A.: Staphylococcus aureus Resists Human Defensins by Production of Staphylokinase, a Novel Bacterial Evasion Mechanism. Journal of Immunology, 172: 1169-76, 2004. 


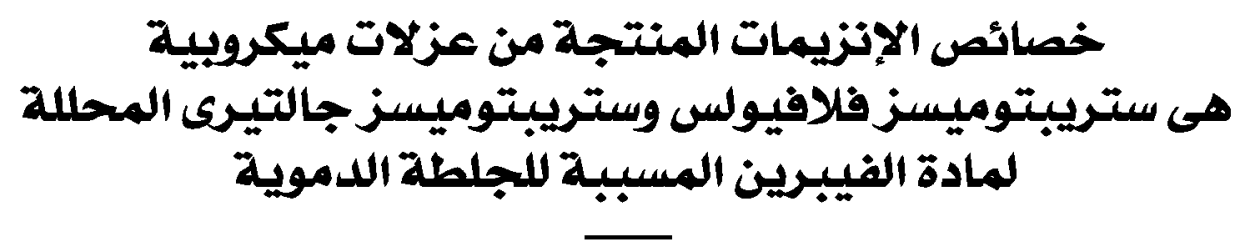

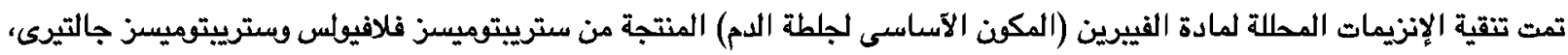

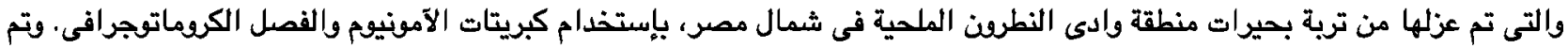

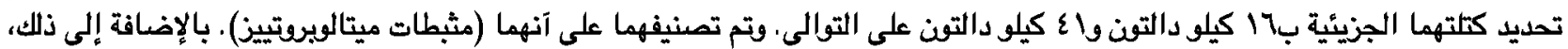

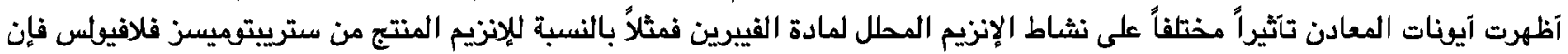

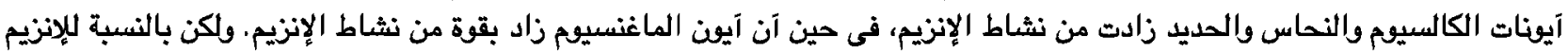

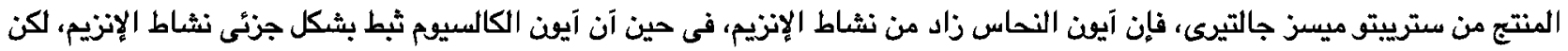

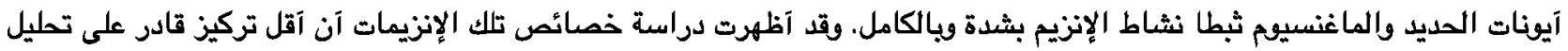

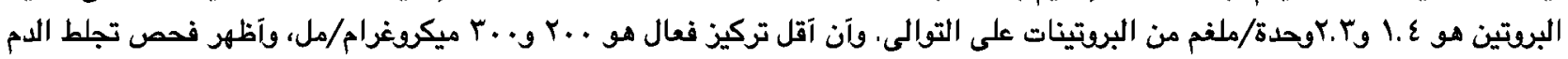

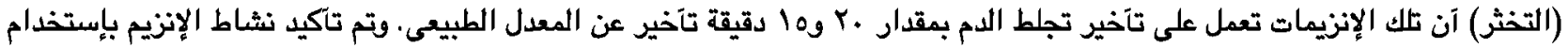

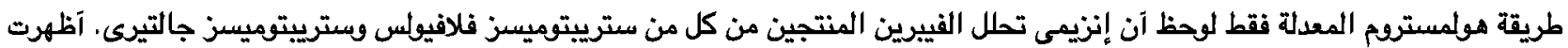

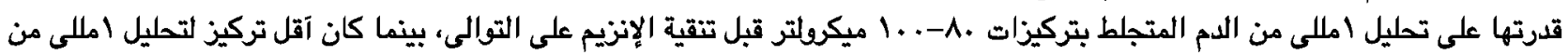

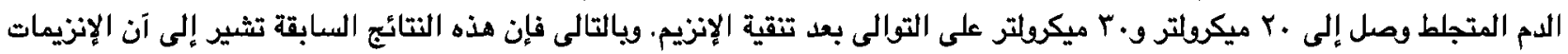

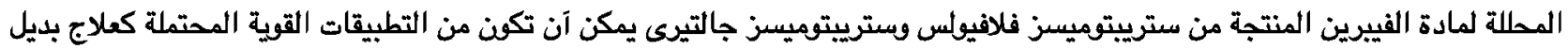

